\title{
INCIDENCE OF ICE CREAM CONTAMINATION WITH COLIFORMS AND FECAL COLIFORMS IN ASSIUT CITY
}

\author{
YASSER S. WAFY \\ Fellow, Assiut University Hospitals
}

Received: 30 September 2019; Accepted: 30 October 2019

\begin{abstract}
A total of 90 random samples of raw cow's milk used in small scale ice cream, small scale ice cream and large scale plain ice cream(30 samples each) collected from Assiut city, Egypt, in the period between from April and September 2019. Each sample was put in ice tank with thermometer to maintain temp. at 4C. The samples were dispatched to the laboratory with a minimum of delay where they were examined for coliforms, fecal coliforms and E.coli true faecal type. The results show that the mean counts of total coliforms in raw cow's milk, small scale and large scale plain ice cream were $2.4 \times 10^{3}, 2.8 \times 10^{2}$ and $1.56 \times 10^{2} \mathrm{cfu} / \mathrm{ml}$ or $\mathrm{g}$., respectively. While the mean counts of fecal coliforms were $2.1 \times 10^{3}, 1.9 \times 10^{2}$ and $1.32 \times 10^{2} \mathrm{cfu} / \mathrm{ml}$ or $\mathrm{g}$., respectively and the mean counts of E.coli true faecal type count cfu/ml or g. were $2.5 \times 10^{2}, 3.3 \times 10^{2}$ and $1.12 \times 10^{2} \mathrm{cfu} / \mathrm{mlor}$ g., respectively. The heath hazards of coliforms, fecal coliforms and E.coli true faecal type, methods of contamination and control were discussed.
\end{abstract}

Key words: raw milk, coliforms, fecal coliforms, E.coli, ice cream.

\section{INTRODUCTION}

Milk and some milk products as ice cream is a nutritionally enriched dairy product consumed by all ages especially children during summer (ElSharef et al., 2006). Milk and some milk products as ice cream is subjected to spoilage or contamination with pathogens during production, handling, processing and distribution.

Common sources of bacterial contamination, especially coliforms are faeces of animal or human origin, personnel, water, and containers. Further contaminations increase for some reasons including the cooling and storage temperatures plus holding time (Murphy and Boor, 2000). A high bacterial count reduces the shelf life of milk and enhances the risk of milk born bacteria infection, so a greater deal of efforts have been made to produce clean milk and milk products to become safe for use and protect it from recontamination by any microorganisms specially from persons who work in production, handling, processing and distribution. The public health hazards of coliforms, fecal coliforms and E. coli has been emphasized by many authors; these enteropathogenic serotypes have been implicated in case of gastroenteritis, epidemic diarrhea in infants, sporadic summer diarrhea in children as well as in

Corresponding author: YASSER S., WAFY

E-mail address: yasserwafy2014@yahoo.com

Present address: Fellow, Assiut University Hospitals case of food poisoning (kornacki and Marth, 1982).

Coliform are routinely used as indicator to the quality of the food products where their presence indicate careless method of handling and the use of insufficient sanitized equipment.

The microbial content of milk and dairy products are a major feature in determining their quality. Several routine examinations such as coliforms count, accepted to test the quality of milk and dairy products. As the coliforms may contaminate the milk which is used in manfacture of ice cream or may recontaminate it during handling by workers.

Therefore this work was planned to detect the incidence of coliforms and fecal coliforms in milk used in manufacture of ice cream and in ice cream after manufacturing in order to improve the sanitary conditions of ice cream.

\section{MATERIALS AND METHODS}

\section{Collection of samples}

A total of 90 random samples of raw cow's milk used in small scale ice cream, small scale ice cream and large scale plain ice cream (30 samples each) collected from Assiut city, Egypt, in the period between April and September 2019. Each sample was put in ice tank with thermometer to maintain temp. at $4 \mathrm{C}$. The samples were dispatched to the laboratory with a minimum of delay where they were examined. 


\section{Preparation of samples (APHA, 1992a):}

1-Raw cow's milk:

$11 \mathrm{ml}$ of well mixed raw cow's milk were added to $99 \mathrm{ml}$ of sterile peptone water $0.1 \%$ to make a dilution of $1 / 10$ from which 10 -fold serial dilutions were made.

\section{2- Ice cream:}

$11 \mathrm{~g}$. of well mixed ice cream samples after melting at room temperature $\left(25^{\circ} \mathrm{C}\right)$ were added separately to $99 \mathrm{ml}$ of sterile peptone water $0.1 \%$ and well mixed to prepare a dilution of 1:10; from which ten -fold serial dilutions were made.

Bacteriological examination for total coli forms and fecal coliforms count (APHA, 1992a):
1- Total coliforms count (MPN) using lauryl sulphate tryptose (LST) broth and Brilliant-green Lactose Bile2\%broth incubated at 35 to $37^{\circ} \mathrm{C}$ for $48 \mathrm{~h}$.

2- Faecal coliforms count using EC broth incubated at $44.5 \mathrm{C}$ for $24 \mathrm{~h}$.

3- E. coli count using Eosine Methylene Blue agar (EMB) incubated at $35^{\circ} \mathrm{C}$ for 18 to $24 \mathrm{~h}$.

4- Biochemical test: Citrate utilization test - Indol production test- Methyl red test- Voges-Proskuer test- Citrate test.

\section{RESULTS}

Table 1: Statistical analytical results of total coliforms count (cfu/ml or g.) in the examined samples.

\begin{tabular}{cccccc}
\hline \multirow{2}{*}{ Sample } & \multicolumn{2}{c}{ Positive sample } & \multirow{2}{*}{ Min. } & Max. & Mean \\
\cline { 2 - 5 } & /No. 30 & $\%$ & & & $2.4 \times 10^{3}$ \\
\hline Raw cow's milk & 30 & 100 & $1.8 \times 10^{2}$ & $3.9 \times 10^{4}$ & $2.8 \times 10^{2}$ \\
\hline small scale Ice-cream & 22 & 73.33 & $1.2 \times 10^{2}$ & $3.7 \times 10^{3}$ & $1.56 \times 10^{2}$ \\
\hline larg scale Ice-cream & 8 & 26.66 & $3.7 \times 10$ & $1.9 \times 10^{2}$ & 2 \\
\hline
\end{tabular}

Table 2: Frequency distribution of the examined samples based on their total coliforms counts (cfu/ml or g.)

\begin{tabular}{|c|c|c|c|c|c|c|}
\hline & \multicolumn{2}{|c|}{ Raw cow milk } & \multicolumn{2}{|c|}{ small scale Ice-cream } & \multicolumn{2}{|c|}{ large scale Ice-cream } \\
\hline $\mathrm{cfu} / \mathrm{ml}$ or $\mathrm{g}$. & No. & $\%$ & No. & $\%$ & No. & $\%$ \\
\hline$*<3$ & - & - & 8 & 26.66 & 22 & 73.33 \\
\hline $3>10^{1}$ & - & - & - & - & 5 & 16.66 \\
\hline $10^{1}-<10^{2}$ & - & _ & - & - & 2 & 10 \\
\hline $10^{2}-<10^{3}$ & 10 & 33.33 & 14 & 46.68 & 1 & - \\
\hline $10^{3}-<10^{4}$ & 16 & 53.33 & 8 & 26.66 & - & - \\
\hline $10^{4-}$ & 4 & 13.3 & - & - & - & - \\
\hline Total & 30 & 100 & 30 & 100 & 30 & 100 \\
\hline
\end{tabular}

* Negative tubes

Table 3: Statistical analytical results of fecal coliforms (cfu/ml or g.) in the examined samples

\begin{tabular}{|c|c|c|c|c|c|}
\hline \multirow{2}{*}{ Sample } & \multicolumn{2}{|c|}{ Positive sample } & \multirow{2}{*}{ Min. } & \multirow{2}{*}{ Max. } & \multirow{2}{*}{ Mean } \\
\hline & /No. 30 & $\%$ & & & \\
\hline Raw cow's milk & 18 & 60 & $1.1 \times 10^{2}$ & $2.6 \times 10^{4}$ & $2.1 \times 10^{3}$ \\
\hline (small scale) Ice-cream & 7 & 31 & $1.0 \times 10^{2}$ & $2.5 \times 10^{3}$ & $1.9 \times 10^{2}$ \\
\hline (large scale) Ice-cream & 2 & 25 & $9.4 \times 10^{1}$ & $1.7 \times 10^{2}$ & $1.32 \times 10^{2}$ \\
\hline
\end{tabular}


Table 4: Frequency distribution of the examined samples based on their faecal coliforms counts (cfu/ml or g.).

\begin{tabular}{|c|c|c|c|c|c|c|}
\hline & \multicolumn{2}{|c|}{ Raw cow milk } & \multicolumn{2}{|c|}{ small scale Ice-cream } & \multicolumn{2}{|c|}{ large scale Ice-cream } \\
\hline cfu/ml or $\mathrm{g}$. & No. & $\%$ & No. & $\%$ & No. & $\%$ \\
\hline$*<3$ & 12 & 40 & 23 & 76.67 & 28 & 93.33 \\
\hline $3-<10^{I}$ & - & $=$ & $=$ & -- & 1 & 3.33 \\
\hline $10^{I}-<10^{2}$ & - & & - & - & - & - \\
\hline $10^{2}-<10^{3}$ & 4 & 13.33 & 5 & 16.67 & 1 & 3.33 \\
\hline $10^{3}-<10^{4}$ & 12 & 40 & 2 & 6.67 & - & - \\
\hline $10^{4}$ & 2 & 6.67 & - & - & - & - \\
\hline Total & 30 & 100 & 30 & 100 & 30 & 100 \\
\hline
\end{tabular}

* Negative tubes

Table 5: Statistical analytical results of E.coli true faecal type counts (cfu/ml or g.) in the examined samples.

\begin{tabular}{cccccc}
\hline \multirow{2}{*}{ Sample } & \multicolumn{2}{c}{ Positive sample } & \multirow{2}{*}{ Min. } & Max. & Mean \\
\cline { 2 - 4 } & /No. 30 & $\%$ & & & $2.5 \times 10^{2}$ \\
\hline Raw cow's milk & 16 & 53.33 & $4.8 \times 10^{1}$ & $1.8 \times 10^{3}$ & $3.3 \times 10^{2}$ \\
\hline (small scale) Ice-cream & 5 & 22.73 & $5.8 \times 10^{1}$ & $2.3 \times 10^{3}$ & $1.12 \times 10^{2}$ \\
\hline (larg scale) Ice-cream & 2 & 25 & $7.4 \times 10^{1}$ & $1.5 \times 10^{2}$ & \\
\hline
\end{tabular}

Table 6: Frequency distribution of the examined samples based on their E.coli true faecal type counts (cfu/mlor g.) in the examined samples.

\begin{tabular}{|c|c|c|c|c|c|c|}
\hline & \multicolumn{2}{|c|}{ Raw cow milk } & \multicolumn{2}{|c|}{ small scale Ice-cream } & \multicolumn{2}{|c|}{ large scale Ice-cream } \\
\hline cfu/ml or g. & No. & $\%$ & No. & $\%$ & No. & $\%$ \\
\hline$*<3$ & 14 & 46.67 & 25 & 83.33 & 28 & 93.33 \\
\hline $3-<10^{I}$ & 1 & 3.33 & 1 & 3.33 & 1 & 3.33 \\
\hline $10^{I}-<10^{2}$ & 1 & 3.33 & 1 & 3.33 & - & - \\
\hline $10^{2}-<10^{3}$ & 4 & 13.33 & 2 & 6.66 & 1 & 3.33 \\
\hline $10^{3}-<10^{4}$ & 10 & 33.33 & 1 & 3.33 & - & - \\
\hline Total & 30 & 100 & 30 & 100 & 30 & 100 \\
\hline
\end{tabular}

* Negative tubes

\section{DISCUSSION}

The results in Table $1 \& 2$ show that 30 (100\%), 22 $(73.33 \%)$ and $8(26.66 \%)$ from examined samples of raw cow's milk, (small scale) Ice-cream and (larg scale) Ice-cream samples were contaminated with coliforms and the total coliform counts $(\mathrm{cfu} / \mathrm{ml}$ or g.) in the examined samples ranged from $1.8 \times 10^{2}$, $1.2 \times 10^{2}$ and $3.7 \times 10$ to $3.9 \times 10^{4}, 3.7 \times 10^{3}$ and $1.9 \times 10^{2}$ with an average count of $2.4 \times 10^{3}, 2.8 \times 10^{2}$ and $1.56 \times 10^{2}$ (cfu/mlor g.), respectively.

The highest frequency distributions were 16 $(53 \%), 14(46.68)$ and 5(16.66) lied within the range of $10^{3}-<10^{4}, 10^{2}-<10^{3}$ and $3-<10^{1}$ in raw cow's milk, (small scale) Ice-cream and larg scale Ice-cream examined samples, respectively.

These results agree with those obtained by Sharma and Joshi (1992), El-Prince and
Hussein (2000), Nawar (2001) and El-Kholy et al. (2018).

Higher results of total coliforms in raw cow's milk were reported by El-Zubeir and Ahmed (2007), while lower results were reported by El-Kholy et al. (2015).

Higher results of total coliforms in ice-cream were reported by Çinar (2010), while lower results were revealed by Delia et al. (1980) and El-Essawy and Riad (1990). El-Kholy et al. (2015).

The stipulated results in Tables $3 \& 4$ indicated that $18(60 \%), 7(31 \%)$ and $2(25 \%)$ of the examined samples of raw cow's milk, (small scale) Ice-cream and (larg scale) Ice-cream samples were contaminated with faecal coliforms and the total faecal coliforms counts (cfu/ml or g.) in the examined samples ranged from $1.1 \times 10^{2}, 1.0 \times 10^{2}$ and $9.4 \times 10^{1}$ to $2.6 \times 10^{4}$, 
$2.5 \times 10^{3}$ and $1.7 \times 10^{2}$ with an average count of $2.1 \times 10^{3}, \quad 1.9 \times 10^{2}$ and $1.32 \times 10^{2}$ (cfu/mlor g.), respectively.

The highest frequency distribution were 12 $(40 \%), 5(16.67 \%)$ and $1(3.33 \%)$ lied within the range of $10^{3}-<10^{4}, 10^{2}-<10^{3}$ and $3-<10^{2}$ in raw cow's milk, small scale Ice-cream and larg scale Ice-cream examined samples, respectively. These results agree with those obtained by El-Kholy et al. (2018).

Higher results of faecal coliforms in raw cow's milk were reported by Meshref (2013), while lower results were reported by El-Kholy et al. (2015). Higher results of faecal coliforms in small scale ice cream were reported by Hassan (2003), while lower results were noticed by Salem (2017).

The presence of coliforms and faecal coliforms in milk and its products indicates either unsanitary conditions during production, processing or storage, (APHA, 1992b) or possibility of post-pasteurization contamination (Robinson, 2002).

Tables 5\&6 show that $16(53.33 \%), 5(22.73 \%)$ and $2(25 \%)$ of examined samples in raw cow's milk, small scale Ice-cream and larg scale icecream samples were contaminated with E.coli true faecal type and the E.coli true faecal type count (cfu/ml or g.) in examined samples ranged from $4.8 \times 10^{1}, 5.8 \times 10^{1}$ and $7.4 \times 10^{1}$ to $1.8 \times 10^{3}, 2.3 \times 10^{3}$ and $1.5 \times 10^{2}$ with an average counst of $2.5 \times 10^{2}, \quad 3.3 \times 10^{2}$ and $1.12 \times 10^{2}$ (cfu/mlor g.), respectively.

The highest frequency distribution were 10 $(33.33 \%), 2(6.66 \%)$ and $1(3.33 \%)$ lied within the range of $10^{3}-<10^{4}, 10^{2}-<10^{3}$ and $3-<10^{2}$ in raw cow's milk, small scale Ice-cream and larg scale ce-cream examined samples, respectively.

Higher results of E.coli in raw cow's milk were obtained by Mohamed (2017) and El Zubeir (2007) while lower results were noticed by Ali et al. (2010). Higher results of E.coli in small scale ice cream were showed by Sobeih et al. (2002), while nearly similar results were demonstrated by Hassan (2003), lower results were detected by Salem (2017) and El-Kholy et al. (2018).

E. coli is a good indicator of fecal pollution and its presence in dairy products indicates presence of other enteropathogenic microorganisms which are considered of public health hazard (Singh and Prakash, 2008).

\section{CONCLUSION}

Milk contaminated with disease causing bacteria does not smell or look any different from non contaminated milk, and there is no obvious way for the consumer to know if the milk is contaminated (Julia, 2010). So great deal of effort must be done to protect clean milk from recontamination from different sources during production, handling, processing and distribution. It is valuable for considering the risk of contamination relating to health problem of the consumers.

The obtained results indicated that unsanitary conditions during production, storage, handling and distribution of raw cow's milk, in dairy farm and manufacturing of Ice-cream (small scale) which often has a poor bacteriological quality than the output of the large scale factory. Most of the examined samples are contaminated with coliforms, faecal coliforms and E.coli which considered as an indicator of poor sanitation and handling of the ice-cream during preparation and fecal contamination from either human or animal sources, and also its presence indicates poor sanitation.

So good hygienic measure must be taken during handling, transportation and storage of milk and avoid lack of cooling in facilities and unsatisfactory transportation means (Oghaiki et al., 2007) to improve the quality of milk and its products to be safe for consumers from exposure to the risk of food infection or intoxication.

Milk must come from dairy farm applied HACCP system in it. Also using of the refrigeration during production, storage, distribution and transportation of the raw milk in dairy farm. Moreover, enhancement of proper personal hygiene practices among all workers sharing in production, storage and handling of produced dairy products. Additionally, application of good manufacturing practices in milk manufacturing units and should be regarded by the regulatory authorities as basic or compulsory requirements. In order to obtain the best bacterial standard which is required, the utmost attention must be given to the cleaning and sanitation of all the plant and equipment used, to the personal hygiene of the entire operator, and to the general cleanliness of the factory.

\section{REFERENCES}

Ali, A.A.; Irshad, N.B.; Razaz, S.A. and Manahil, A.A. (2010): Microbiological safety of raw milk in Khartoum State, Sudan. Pakistan J. 
Nutrition, 9 (5): 426-429.

APHA (1992a): Standard Methods for the Examination of Dairy Products. 3rd ed., American Public Health Association, Washington.

APHA (1992b): Compendium of Methods for the Microbiological Examination of Foods. 3rd ed., American Public Health Association, Washington

Çinar, E. (2010): The research of microbial characteristic of plain and Strawberry flavored ice cream samples sold in Tekirdag. M.V.Sc. Thesis, Çukurova University.

Delia, S.; Mauro, A. and Dania, D. (1980): Application of Ministerial Ordinance of 11 October 1978 on ice-cream in the city of Messina. Italiana Discienza dell' Almentaziane, 9, 6,437. Dairy Science Abst., 43, 10(1981).

El-Essawy, H.A. and Riad, A.A.M. (1990): Incidence of Coliform organisms in cream and icecream with special reference to enteropathogenic strains of E.Coli. Assiute Veterinary Medical Journal, Vol. 24, No.47.

El-Kholy, A.M.; Hassan, G.M.; Shehata, A.A.E. and Mohamed, E.A.S. (2015): Studies on enteric pathogens In milk and some dairy products with special reference to salmonella. Egypt. J. Appl, Sci., 30 (6). 55: 69.

El-Kholy, A.M.; Hassan, G.M.; Shehata, A.A.E. and Bakr, A. (2018): INDICATOR MICROORGANISMS AS INDICES OF QUALITY FOR MILK AND SOME DAIRY PRODUCTS. Journal Assiut Vet. Med. J. Vol. 64 No. 158

El-Prince, E. and Hussein, A.A. (2000): Occurrence of Enterobacteriaceae in ice-cream with special reference to Salmonella species. Assiute Veterinary Medical Journal, Vol. 45, No.89.

El-Sharef, N.; Ghanghesh, K.S.; Gnan, Y.A.S. and Rahouma, A. (2006): Bacteriological quality of ice cream in Tripoli-Libya. Food Control., 17(8): 637-641.

El-Zubeir, I.E.M. and Ahmed, M.I.A. (2007): The hygienic quality of raw milk produced by some dairy farms in khartoum state, Sudan. Research J. Microbiol., 2: 988-991.

Hassan, G.M. (2003): Quality assessment of some dairy products at consumer level. Ph.D. Thesis, Fac. Vet. Med., Cairo Univ. BeniSuef branch, Egypt

Julia, H. (2010): illness Outbreaks in Utah Linked to Row milk .News Release, Monday, May 16.

Kornacki, J.L. and Marth, E.H. (1982): Food- borne illness caused by E. Coli A review. Journal of Food Protection, 45; 1051.

Meshref, A.M.S. (2013): Bacteriological quality and safety of raw cow's milk and fresh cream. Slov. Vet. Res., 50(1): 21-30.

Mohamed, M.M.A. (2017): Staphylococcus aureus in milk and some milk products sold in Fayoum. M.V.SC. Thesis, Fac. Vet. Med., Assiut Univ., Egypt.

Murphy, S.C. and Boor, K.J. (2000): Troubleshooting sources and causes of high bacteria counts in raw milk. Dairy Food Environ. Sanit., 20: 606-611.

Nawar, D.M.M. (2001): Hygienic quality of some street vender dairy products. M.V.Sc.Thesis, Faculty of Veterinary Medicine Alex. University

Oghaiki, N.A.; Fonteh, F.; Kamga, P.; Mendi S. and Imele, H. (2007): Activation of the 1sctoperoxidise system as a method of preserving raw milk in areas without cooling facilities. Afr. J. Food Agric. Nutr. Dev., 7: 1-

Robinson, R.K. (2002): Dairy Microbiology Hand Book. 3 rded.

Salem, H.A.M. (2017): Quality criteria for some dairy products. M.V.SC. Thesis, Fac.Vet. Med., Beni-Suief Univ., Egypt

Sharma, D.K. and Joshi, D.V. (1992): Bacteriological quality of milk and milk products with special reference to Salmonella and its Public health significance. Journal of Food Science Technology Mysore, 29(2): 105-107.

Singh, P. and Prakash, A. (2008): Isolation of E.coli, Staphylococcus aureus and Listeria monocytogenes from milk products sold under market conditions at Agra Region, Acta agriculturae Slovenica, 92 (1): 83-88.

Sobeih, A.M.K.H.; Al-Hawary, I.I. and Aman, I. (2002): Microbiological quality of milk and ice cream sold in Kafr El-Sheikh and ElGharbia Governorates. Minufiya Vet. J., 2(1) 


\section{معدل تلوث الآيس كريم بيكتريا القولونية والقولونية البرازية في مدينة أسيوط}

\section{باسر وافح \\ E-mail: yasserwafy2014@yahoo.com Assiut University web-site:www.aun.edu.eg}

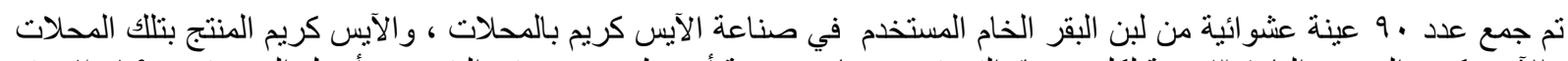

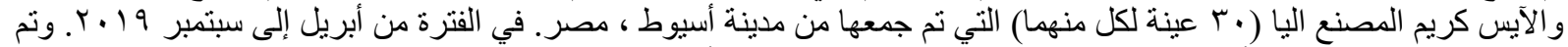

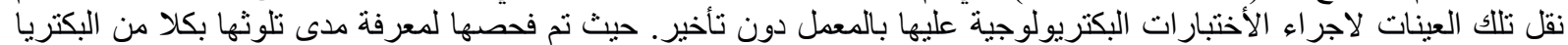

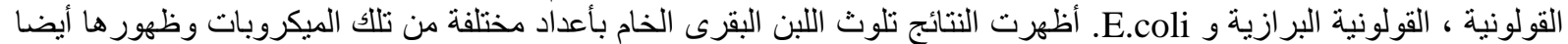
فى كلا من الأيس كريم المصنع بالمحلة المنات و الآيس كريم المصنع أليا.

وتم مناقثة طرق أنتقال تللك الميكربات الىى اللبن بالمزارع الأيس كريم المصنع بالمحلات وبالمصانع الكبرى وطرق السيطرة على

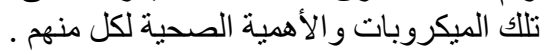

